\title{
EWOLUCJA POJĘCIA MASY
}

\author{
WPRO:WADZENIE
}

Często mówi się, że fizyka jest „nauką o materii i jej przemianach”. Tymczasem w słowniku fizyki termin „materia” w ogóle się nie pojawia, chociaż prawdą jest, iż fizycy - jeśli przestają dbać o pedantyczną ścisłość swoich wypowiedzi - dość często posługują się tym terminem. Intuicyjnie najbliższym znaczeniowo terminowi „materia” jest fizyczny termin „masa”. Obydwa terminy mają wspólną genealogię w języku potocznym, obydwa przeplatają się znaczeniami w dziejach filozofii i przyrodoznawstwa przed powstaniem nauk przyrodniczych. Potem ich historie się rozchodzą, pozostawiając jednak w umysłach wielu ludzi sporo zamieszania i nieporozumień. Celem tego studium jest wyjaśnienie przynajmniej niektórych spośród nich. Nie mam zamiaru pisania oryginalnej historii, ani nawet przyczynku do historii, pojęcia masy. Zamiar taki został już zresztą pięknie zrealizowany przez Maxa Jammera w jego monografii Concepts of Mass ${ }^{1}$, z której w niniejszym studium obficie korzystam. Wszystkie źródła, do jakich odwołuję się nie w przypisach lecz w tekście, w okrągłych nawiasach, są cytowane za Jєmmerem. Począwszy od rozdziału trzeciego właściwymi odnośnikami byłyby podręczniki fizyki współczesnej; zacytowany jest tylko jeden i to głównie celem ożywienia narracji. Odwołuję się również do kilku prac oryginalnych; nie jest to wszakże pełna dokumentacja lecz jedynie dość przypadkowy zestaw na zasadzie przykładów z literatury.

Zagadnienie wydaje się doniosłe. Pojęcie materii jest kluczowym dla wielu systemów filozoficznych i zbadanie fizycznej zawartości tego pojęcia może się okazać wysoce interesujące.

1 Concepts of Mass in Classical and Modern Physics, Harvard University Press, Cambridge Mass. 1961. 


\section{Z PRZEDNAUKOWEJ HISTORII ZAGADNIENIA}

Współczesny termin „masa” (ang.: mass, franc.: masse) pochodzi od łacińskiego „massa”, co pierwotnie oznaczało kawałek ciasta lub pasty (por. np. masa tortowa). Nie wykluczone, że termin łaciński pochodzi z kolei od greckiego $\mu \alpha \zeta \alpha$ (maza), pierwotnie: ziarno jęczmienne, potem (Herodot): chleb gorszego gatunku.

Konieczność wymiany towarów jeszcze w głębokiej starożytności doprowadziła do powstania pojęcia ilości materii; miało być ono odpowiedzią na pytanie: jak wiele czegoś? Odpowiedź na to pytanie można było uzyskać odwołując się do ciężaru lub do objętości. W praktyce posługiwano się obydwiema metodami. Wkrótce jednak pytanie ,jak wiele czegoś? - kategoria ilości - postawiono także w filozofii. Tu wszakże za miarę , ,ilości materii" nie uznano ani ciężaru, ani objętości. Tak na przykład postąpił Arystoteles. W jego pismach termin „materia” (hylé) znaczył pierwotnie drewno lub las, co prawdopodobnie zasugerowało mu, by wypracowanemu potem pojęciu substratu, podłoża zjawisk, na określenie którego użył tego samego terminu, przypisać cechy organiczne; stąd podłoże to może ulegać pomniejszeniu lub powiększeniu. Pogląd ten z kolei spowodował, że Arystoteles nie sformułował niczego w rodzaju zasady ,zachowania materii”.

Według Arystotelesa ruch jest wynikiem działania dwóch sił: siły poruszającej i siły oporu. Obydwie one są czymś zewnętrznym w stosunku do poruszającego się ciała. Doktryna ta sprawiła, że wiele stuleci trzeba było czekać na utwoṛzenie się pojęcia masy jako miary oporu stawianego przez dane ciało przyspieszającej je sile. Traktowanie materii jako czegoś całkowicie biernego, ulegającego tylko działaniom sił zewnętrznych, było następstwem metafizycznych poglądów Arystotelesa, zgodnie z którymi materia (pierwsza) jest czystą możnością, mogącą tylko przyjmować różne formy.

Późniejsi perypatetycy za miarę ilości materii przyjmowali przestrzenną rozciągłość ciała. Było to przeniesieniem na teren fizyki geometrycznej definicji $\mathrm{E} \mathrm{uklides} a$ : „ciałem jest to, co ma długość, szerokość i głębokość".

Doktrynie tej przeciwstawili się sto i c y, twierdząc, że fizyka jest czymś więcej niż geometrią, a ciało czymś więcej niż swoją rozciągłością. S e kstus Emiryk głosił, że ciało fizyczne to jest coś, co posiada wielkość, formę (kształt), ciężar i zdolność stawiania oporu. Pierwsze dwa atrybuty są własnościami geometrycznymi, drugie dwa - fizycznymi.

Pojęcie bezwładności (inercji) po raz pierwszy pojawiło się w ne oplatonizmie. Według tego systemu materia zajmuje najniższe 
miejsce w hierarchii bytów, jest całkowicie bierna i do jej istoty należy bezwładność w znaczeniu absolutnego braku ,aktywności czyli formy". Ploty n uczył ponadto, że bierność czyli bezwładność materii jest następstwem jej rozciągłości.

Neoplatońskie rozumienie materii i jej bezwładności przetrwało $u$ wielu myślicieli średniowiecza. Napotykamy je między innymi u Alkuina, Anzelma z Canterbury, Hugona od św. Wiktora, Piotra Abelarda, Piotra Lombarda i wielu innych.

U filozofów arabskich występuje pojęcie formy cielesności, różnej od arystotelesowskiej formy substancjalnej. A 1-Ghazali twierdził, na przykład, że forma cielesności nadaje materii pierwszej „masywność", a A we r roes przypisywał materii pierwszej podzielność czyli ,posiadanie ilości". Poglądy filozofów arabskich były poważnym krokiem na drodze kształtowania się pojęcia ,ilości materii”.

Ostatni krok na tej drodze został postawiony przez ucznia św. Tomasza z Akwinu, Egidiusza Rzymskiego w związku z... teologicznym traktatem o Eucharystii. Problem dotyczył transsubstancjacji: jak istnieją przypadłości chleba po konsekracji? W trakcie rozważań tej kwestii Egidiusz rozróżnił dwie ,ilości” przysługujące materii: objętość i „ilość materii”. Argumentem uzasadniającym to rozróźnienie było powołanie się na zgęszczanie i rózrzedzanie ciała, kiedy to objętość ulega zmianie a ,ilość materii" pozostaje ta sama. Według Egidiusza to właśnie ,ilość materii” jest substratem dla przypadłości chleba po konsekracji.

Pojęcie ilości materii weszło do późnośredniowiecznego przyrodoznawstwa. Tak na przykład Burydan w swojej teorii impulsu głosił proporcjonalność impulsu do ilości materii. „Im więcej materii - pisał - tym więcej dane ciało może przyjąć impulsu i o tym większej intensywności". (Questiones super octo libros Physicorum, liber 8 , questio 12). Można tu już uważać ilość materii za miarę oporu, jaki ciało stawia działającemu nań impulsowi. Podobne idee spotykamy u Mikołaja Oresme.

\section{POWSTANIE FIZYCZNEGO POJECIA MASY}

Zdaniem wielu historyków myśli ludzkiej nowożytna nauka zaczyna się od Galileusza; uczony ten nie miał jeszcze jasnego pojęcia masy. W Dialogu Salviati wypowiada zdanie: ,...ciało ruchome, poza naturalną skłonnością do odwrotnego kierunku, ma jeszcze przyrodzo- 
ną mu i naturalną właściwość, wywołującą opór przeciwko ruchowi" ${ }^{2}$, zdające się wskazywać na dość klarơwne rozumienie masy inercjalnej, ale wyrażenia w rodzaju ,naturalna skłonność” czy ,przyrodzona właściwość" zdecydowanie zaciemniają obraz. U podstaw mechaniki Galileusza leżą pojęcia długości i czasu, jako dających się mierzyć wielkości, ale brak jeszcze fizycznego pojęcia masy.

Krok naprzód uczynił $\mathrm{K}$ e p 1 e r. Wprawdzie i on natchnienie czerpał z nieco mistycznych porównań siły do aktywności ducha i materii do czynnika stawiającego opór tego rodzaju aktywności, niemniej jednak głębokie rozważania nad dynamiką ruchów planet doprowadziły go do trafnych sformułowań. Ponieważ okresy poszczególnych planet różnią się od siebie, to ,,jest rzeczą oczywistą, że materia musi posiadać bezwładność, która wyjaśnia te różnice" (Kepler, Opera omnia, pod rẹ. C. Frisha, Frankfurt-Erlangen, tom 6, 1896, s. 342). Kepler związał scholastyczne pojęcie ilości materii (copia materiae) z nowym pojęciem bezwładności (inertia). „Bezwładność - pisał - czyli przeciwstawianie się ruchowi, jest charakterystyką materii i jest tym większa, im większa jest ilość materii w danej objętości" (ibid., s. 174-175). U Keplera pojawia się również pojęcie masy; w następującym kontekście: „Jeżeli umieścić dwa kamienie w pobliżu siebie, w jakimkolwiek miejscu wszechświata, poza sferą wpływu jakiegoś trzeciego ciała, to te dwa kamienie - na podobieństwo magnesów - spotkają się ze sobą, zbliżając się do siebie na odległość proporcjonalną do ich masy (moles)" (ibid., s. 151).

Zdaniem Jammera proces formowania się pojęcia masy został zahamowany przez fizykę Karteıjus z a, który — zgodnie ze swoją koncepcją materii jako rozciągłości - ilość materii utożsamiał nie $\mathrm{z}$ masą lecz po prostu z objętością. Masa w systemie Kartezjusza była zbyteczna.

Prace Borelle go na temat pojęcia ciężaru i $\mathrm{H}$ u y ge n s a zderzeniach ciał spowodowały, że sytuacja ostatecznie dojrzała do pełnej systematyzacji. Stało się to zasługą I z a a k a $\mathrm{N}$ e w t o n a. Oto sławna definicja z Philosophiae Naturalis Principia Mathematica: „Ilość materii (masa) jest to przysługująca jej miara, proporcjonalna do jej gęstości i objętości". Tak zdefiniowaną masę Newton niekiedy wręcz utożsamiał z ciałem: ,w dalszym ciągu - pisał Newton - ilość tę nazywam ciałem lub masą" (ibid.). Obok pojęcia ilości materii, czyli masy, Newton zdefiniował pojęcie ilości ruchu. „Ilość ruchu - czytamy w „Principiach" - jest to przysługująca ruchowi miara proporcjonalna prędkości i masie". W definicji tej rozpoznajemy, rzecz jasna, określenie

${ }^{2}$ Galileo Galilei, Dialog o dwu najważniejszych układach świata, przekł. E. Ligocki, PWN, 1962, s. 231. 
pędu. Każde ciało - zdaniem Newtona - posiada „wrodzoną siłę” czyli „przysługującą mu możliwość przeciwstawiania się, nakazującą każde$\mathrm{mu}$ oddzielnie rozważanemu ciału, o ile jest ono pozostawione samemu sobie; pozostawanie w tym samym stanie spoczynku lub jednostajnego, prostoliniowego ruchu" (ibid.). Twórca nowożytnej mechaniki uznał za stosowne zaopatrzyć to określenie następującym komentarzem: „Siła ta jest zawsze proporcjonalna do masy i jeżeli w ogóle różni się ona od bezwładności masy, to tylką kątem widzenia" (ibid.). To właśnie siła inercji - Newton używa tego określenia - nakazuje ciałom pozostawać w tym samym stanie spoczynku lub ruchu, o ile nie działają na nie inne'siły.

Jeśli spojrzeć na dzieło Newtona $\mathrm{z}$ dzisiejszego punktu widzenia, jest ono wyraźnie wielowarstwowe. Obok warstwy matematyczno-fizycznej znajduje się w nim bogata warstwa filozoficzna. Należy pamiętać, że była to epoká, w której fizyka dopiero powoli wyłaniała się z dotychczas wszechobejmującej filozofii, a sam Newton bardziej uważał się za filozofa przyrody niż za „mechanika”. Ponadto, jak widzieliśmy na przykładzie przednewtonowskiej ewolucji pojęcia materii, proces przekształcania się tradycyjnych pojęć filozoficznych w pojęcia empiryczne dokonywał się żmudnie i stopniowo. Nawet $w$ dziele Newtona pępowina łącząca te dwie klasy pojęć nie została jeszcze definitywnie przecięta. Wprawdzie można zasadnie twierdzić, że w ściśle matematyczno-fizycznej warstwie Principiów pojęcie materii przestało odgrywać jakąkolwiek rolę, to jednak pozostało ono nadal kluczem do zrozumienia newtonowskiej filozofii przyrody ${ }^{3}$.

Fakt, że Newton terminologidznie utożsamił masę z ilością materii świadczy o tym, że wiązał on pojęcie masy $\mathrm{z}$ „pojęciem materialności. Materia zaś dla Newtona była - zgodnie $\mathrm{z}$ odziedziczoną przez niego tradycją filozoficzną - podłożem (substratem) dla tzw. własności pierwotnych, tzn. takich własności, które przysługują wszystkim ,gatunkom" bytów występujących w przyrodzie. Do własności pierwotnych, za swoimi poprzednikami, Newton zaliczał: rozciągłość, nieprzenikliwość, bezwładność i podleganie ruchowi; od siebie zaś dodał do tej listy zdolność przyciągania grawitacyjnego i zdolność bycia przyciąganym grawitacyjnie.

Zdolność przyciągania grawitacyjnego poddawała w wątpliwość tradycyjną tezę o całkowitej bierności materii. Rzecz interesująca, mimo iż Newton zdawał sobie sprawę z tej trudności, nadal próbował podtrzymywać tradycyjne twierdzenie. Problem ten stał się jednym z centralnych zagadnień późniejszej filozofii przyrody. Argumenty za aktyw-

${ }^{3}$ Por. E. McMullin, Newton on Matter Activity, University of Notre Dame Press, Notre Dame-London, 1978. 
nością materii zaczęły z czasem zdecydowanie brać górę, torując drogę osiemnasto- i dziewiętnastowiecznemu materializmowi.

Jak dziś dobrze wiadomo, mechanikę klasyczną można bardzo elegancko przedstawić $w$ postaci geometrycznej ${ }^{4}$. Tak sformalizowana fizyka tym różni się od geometrii, że oprócz wszystkich pojęć geometrycznych wprowadza jeszcze kilka pojęć charakterystycznych dla siebie, a wśród nich pojęcie masy. Z niewielką przesadą można by powiedzieć, że mechanika klasyczna to geometria plus pojęcie masy. Ta niegeometryczność pojęcia masy do dziś w umysłach wielu ludzi (wśród nich także i fizyków) wiąże się $\mathrm{z}$ intulicją pojęcia materii. Stąd właśnie biorą początek przekonania o tym, że fizyka jest nauką o materialnym świecie.

\section{DYGRESJA NA TEMAT FILOZOFICZNYCH SPORÓW O MATERIE}

Wprawdzie już w fizyce klasycznej pojęcie materii zostało przetłumaczone a potem całkowicie zastąpione pojęciem masy, która z kolei została zredukowana do roli parametru w równaniach ruchu, jednakże filozofowie - także i ci pragnący opierać swoje dociekania wyłącznie na naukach przyrodniczych - zupełnie nie zauważyli tego niezwykle ważnego procesu. Spory o „naukowe” rozumienie materii bardzo często były jądrem ówczesnych rozważań i światopoglądowych polemik. Mimo, że rozwój nauki pozostawił te rozważania i polemiki zupełnie na boku, poświęćmy im jednak nieco uwagi ze względu na fakt, że ich filozoficzne następstwa do dziś nieproporcjonalnie przeẃyższają ich prawdziwą wartość. Nie podejmuję nawet próby przedstawienia ewolucji tego problemu; zatrzymam się jedynie nad poglądami kilku autorów, traktując je jako ,niedoskonałą próbkę".

Koncepcja materii jako podłoża własności, utrzymywana przez Newtona, cieszyła się dużą popularnością w XVII i XVIII stuleciu. W tym ujęciu - jak pisze Weyl w swoim znakomitym acz zwięzłym studium o pojęciu materii - „ciało zawiera pewne niezmienne substancjalne jądro, będące nośnikiem zmiennych jakości zmysłowych, które spostrzegamy jako tkwiące w spostrzeganej rzeczy..." ${ }^{5}$. Zmienne doznania zmysłowe muszą być wywierane - zdaniem Boyle'a i Locke'a - na nasze władze poznawcze przez coś, co dzieje się w samym ciele mate-

4 Por. np.: W. I. Arnold, Metody matematyczne mechaniki klasycznej, PWN, Warszawa 1981; R. S. Ingarden, A. Jamiolkowski, Mechanika klasyczna, PWN, Warszawa-Poznań, 1980; J. J. Sławianowski, Geometria przestrzeni fazowych, PWN, Warszawa 1975.

5 . H. Weyl, Philosophy of Mathematics and Natural Science, Atheneum, New York 1963, rozdział III, s. 165. 
rialnym. $\mathrm{Z}$ punktu widzenia mechanicyzmu najnaturalniej było przyjąć, że doznania zmysłowe są powodowane przez ruchy „elementów składowych" ciał. Taka koncepcja prowadziła prosto do atomizmu. Istotnie, starogrecki atomizm odrodził się w XVII wieku; jego wskrzesicielem był Gassendi. Fizyczne konsekwencje atomistycznego rozumienia materii usiłował sformułopwać $\mathrm{H}$ u y g g e ns; doszedł on nawet do wniosku, że ciepło jest ruchem atomów, zaplątał się jednak w nieprzezwyciężalne kłopoty, gdy w oparciu o fakty obserwacyjne i prawa mechaniki usiłował wyliczyć rozmiary i masy atomów.

$\mathrm{W}$ atomistycznych ujęciach jedną $\mathrm{z}$ głównych cech materii była bezwładność i nie istniała konieczność znaczniejszych odstępstw od tradycyjnej doktryny o bierności materii. Wielki rywal Newtona, Wilhelm Got fryd Leibniz propagował dynamiczny pogląd na świat. Substancja, według niego, to nie tyle podłoże własności ile po prositu „siła pierwotna" (une force primitive). Leibniz rozumiał dynamizm materii metafizycznie, wkrótce jednak zjawili się myśliciele, którzy istotę materii sprowadzili do siły rozumianej mniej lub bardziej w duchu mechaniki Newtona. Tak uczynił $\mathrm{R}$ obert $\mathrm{Greene,} \mathrm{filozof} \mathrm{z}$ Cambridge, w swoim dziele The Principles of Natural Philosophy (1712); dla niego aktywność materii była jej cechą istotną.

Zamiarem R. Boscovicha było pogodzić stanowiska Newtona i Leibniza. Za zwolennikami pierwszego uznawał on rodzaj atomizmu; starał się upodobnić do drugiego, utrzymując, że atomy mają rozmiary punktowe i są niczym innym jak tylko „centrami sił”. Do koncepcji tej przychylał się także $\mathrm{C}$ a u $\mathrm{ch}$ y i $\mathrm{A} \mathrm{mpèr} \mathrm{e,} \mathrm{a} \mathrm{K}$ a n t w swoim „Anfgangs - gründe der Naturwissenschaft" (1794) opowiedział się za poglądem, że istotę materii stanowi współdziałanie sił odpychających i przyciągających; wszystkie własności materii, łącznie z jej rozciągłością, dadzą się sprowadzić do tego oddziaływania.

Kropkę nad i postawił J. Priestle y, który po prostu utożsamił materię z siłą. W ten sposób, patrząc z jednej strony, można powiedzieć, że materia została całkowicie odmaterializowana, ale patrząc z drugiej strony można stwierdzić, że siła została zmaterializowana. Ten drugi punkt widzenia okazał się bardziej płodny w historyczne następstwa; otworzył on drogę do materialistycznych metafizyk, stawiających znak równości pomiędzy materią a wszystkim, co istnieje.

Jak widać $\mathrm{z}$ przeprowadzonych dotychczas analiz, materializm nie był - wbrew rozpowszechnionym przekonaniom - konsekwencją fizyki klasycznej, lecz następstwem przeoczenia przez najbardziej wpływowych filozofów faktu, że fizyka klasyczna wyeliminowała pojęcie materii ze zbioru swoich teoretycznych narzędzi.

Dokonajmy teraz krótkiego przeglądu tego zbioru. 


\section{KLASYCZNE DEFINICJE PODRĘCZNIKOWE}

W mechanice klasycznej, z pojęciowego punktu widzenia, należy starannie odróżnić masę bezwładną (inercjalną) i masę grawitacyjną.

M a s a be z ładna jest miarą bezwładności ciała, czyli miarą oporu jaki ciało stawia przyspieszającej go sile. Iloczyn masy bezwładnej $\mathrm{m}$ i prędkości $\overline{\mathrm{v}}$ ciała względem danego układu odniesienia nazywa się pędem: $\overline{\mathrm{p}}=\mathrm{m} \overline{\mathrm{v}}$.

W szczególnej teorii względności zakłada się, że w pewnej wyróżnionej klasie układów odniesienia, zwanych układami inercjalnymi, spełniona jest zasada zachowania pędu. Prowadzi to do wniosku, że masa bezwładna zależy od prędkości ciała; zależność ta wyraża się następującym związkiem: $m=m_{0}\left(1-v^{2} / c^{2}\right)^{-1 / 2}$, gdzie c jest prędkością światła w próżni, a mo tzw. masą spoczynkową, czyli masą mierzoną w układzie odniesienia, względem którego ciało znajduje się w spoczynku.

$\mathrm{Z}$ aksjomatów szczególnej teorii względności wynike związek: $\mathrm{E}=$ $=\mathrm{m} \mathrm{c}^{2}$, stwierdzający, że masa $\mathrm{m}$ i całkowita energia $\mathrm{E}$ są dwiema miarami tej samej wielkości fizycznej; wielkość tę można mierzyć bądź w jednostkach masy, bądź w jednostkach energii, współczynnikiem przeliczającym jedne jednostki na drugie jest kwadrat prędkości światła.

Masa grawitacy jna jest miarą oddziaływania pomiędzy danym ciałem a polem grawitacyjnym. Pomimo stwierdzonej doświadczalnie, z dużą dokładnością, równości masy bezwładnej i masy grawitacyjnej (doświadczenie Eőtvősa, 1909, i Dicke'go, 1961, 1964), w fizyce przedeinsteinowskiej masa bezwładna i masa grawitacyjna były traktowane jako dwa zupełnie odrębne pojęcia, a równość tych mas należało uważać za przypadkową. Chęć usunięcia tej przypadkowości była jednym z głównych motywów stworzenia ogólnej teorii względności. Tzw. zasada ró w no w a ż ności, postulująca identyczność masy bezwładnej i masy grawitacyjnej, była dla Einsteina punktem wyjścia w stworzeniu jego nowej teorii. Zasada ta jest zawarta w formalizmie ogólnej teorii względności.

5. MASA W MECHANICE KWANTOWEJ I W KWANTOWEJ TEORII POLA

Według powszechnie panującego dziś poglądu fizyka klasyczna (makroskopowa) jest statystycznym uśrednieniem zjawisk mikroświata. A zatem podstawowych wyjaśnień fizycznych należy szukać w obszarze kontrolowanym przez fizykę kwantową. Tymczasem pojęcie masy przeszło prawie niezmienione $\mathrm{z}$ fizyki klasycznej do mechaniki kwantowej na mocy tzw. zasady korespondencji. Masa pojawia się w forma- 
lizmie mechaniki kwantowej jako parametr i nawet nie stawia się pytania, czy jest ona wielkością obserwowalną i czy można ją przedstawić w postaci operatora, tak jak przedstawia się wielkości obserwowalne w mechanice kwantowej.

W elektrodynamice kwantowej, opracowanej przez Diraca, Heisenberga, Jordana, Fermiego, fotony były traktowane jako stany skwentowanego pola elektromagnetycznego, natomiast cząstki jako stany skwantowanego pola elektronowo-pozytronowego. Zakładało się, że masa cząstki powinna być wynikiem wzajemnego oddziaływania cząstki i pola. Masę taką nazywamy mas ą polow ą. Spodziewano się, że cała masa cząstki będzie jej masą polową. Niemal od samego początku stało się jednak jasnym, że wyrażenia, które miały by opisywać tego rodzaju ,generację masy" prowadziły do całek rozbieżnych, czyli dawały masy nieskończone. Było to jedną z największych trudności elektrodynamiki kwantowej. Proponowano wiele metod - niekiedy wielce egzotycznych - by tej trudności zaradzić. W standardowym wykładzie elektrodynamiki kwantowej stosuje się tzw. zabiegi r e n o rmaliza c ji, stanowiące zbiór przepisów, jak praktycznie radzić sobie $\mathrm{z}$ nieskończonymi wielkościami. U podstaw tych przepisów leży nie tyle ścisłość martematyczna ile raczej ,sens fizyczny”. Właśnie w występowaniu tego rodzaju rozbieżności przejawia się logiczna niezupełność aktualnej elektrødynamiki kwantowej, „...w teorii tej można ustanawiać określone »przepisy«, pozwalające w jednoznaczny sposób przeprowadzać »odejmowanie nieskończoności« i otrzymywać w rezultacie skończone wartości dla wszystkich wielkości mających bezpośredni sens fizyczny. U podstaw tych »przepisów « leżą oczywiste przesłanki fizyczne, sprowadzające się do żądania, żeby masa fotonu była równa zeru, a ładunek i masa elektronu były równe ich wartościom obserwowanym" 6 .

We współczesnych wersjach teorii pól kwantowych również masa nie pojawia się w sposób naturalny. W teoriach tych wprowadza się często dodatkowy aparat formalny, zwany me chan i z m e m H ig g s a, który generuje masę. Zgodnie $\mathrm{z}$ tym mechanizmem czymś pierwo'tnym są formalne symetrie rozważanego systemu, a pojawienie się masy jest związane $\mathrm{z}$ ich łamaniem ?.

6. E. M. Lifszic, L. P. Pitajewski, Relatywistyczna teoria kwantów, część II, PWN, Warszawa 1973, s. 40.

7 Por. np. A. Trautman, Fiber Bundles, Gauge Fields, and Gravitation, w: General Relativity and Gravitation - One Hundred Years after the Birth of Albert Einstein, vol. 1, ed. by A. Held, Plenum Press, New York-London, 1980, s. $287-308$. 


\section{Z PROBLEMATYKI MASY W OGOLNEJ TEORII WZGLĘDNOSCI}

W ogólnej teorii względności énergia-masa pola grawitacyjnego ${ }^{3}$ nie jest wielkością niezmienniczą, tzn. zależy ona od wyboru układu odniesienia, w którym jest mierzona. Własność ta do dziś bulwersuje. wielu teoretyków, którzy zaproponowali szereg modyfikacji ogólnej teorii względności celem zaradzenia temu kłopotowi. Wielu innych, po prostu akceptując jeszcze jedno odejście współczesnej fizyki od „zdrowego rozsądku", stara się do końca wyprowadzić konsekwencje z tego faktu. I tak na przykład okazuje się, że w obszernej klasie kosmologicznych rozwiązań równań Einsteina, w pobliżu tzw. początkowej osobliwości, gdzie występują niezwykle silne pola grawitacyjne (duże krzywizny czasoprzestrzeni), można praktycznie nieograniczenie „wydobywać” energię $\mathrm{z}$ pola grawitacyjnego (czyli z zakrzywienia czasoprzestrzeni) i stosując mechanizmy teorii pól kwantowych $-z$ energii tej tworzyć cząstki elementarne. Istnieje dziś wiele wersji tego procesu ${ }^{9}$. Inne koncepcje wykorzystują „operatory tworzenia cząstek” bezpośrednio do „fluktuacji próżni” ${ }^{10}$. Warto przy tym nadmienić, że we wszystkich tych teoriach zasady zachowania są ściśle spełnione, gdyż powstają równe ilości cżąstek i antycząstek, tak że suma zachowywanych wielkości przed i po produkcji jest równa zeru. Mielibyśmy tu do czynienia dosłownie $\mathrm{z}$ ideą twonzenia świata $\mathrm{w}$ nicości, gdyby nie fakt, że próżnia w sensie fizycznym zasadniczo różni się od filozóficznego niebytu.

Pod pewnym względem podobną próbę stworzenia masy z czasoprzestrzeni podjąl już wcześniej J. A. Wh e el e r. Postulował on samozakrzywianie się czasoprzestrzeni do postaci stabilnych konfiguracji, zwanych przez niego geonami, które miały być modelami cząstek elementarnych obdarzonych masą (,masa bez masy" - według wyrażenia Wheelera). Program ten $\mathrm{z}$ czasem został porzucony, gdyż prowadził do mas zbyt dużych $\mathrm{w}$ porównaniu $\mathrm{z}$ masami cząstek elementarnych znanymi z doświadczenia. Pomysł Wheelera dotyczący masy był częścią ogólniejszego programu, propagowanego w swoim czasie przez tego fizyka a polegającego na ,zbudowaniu całej fizyki z czasoprzestrzeni”. Program ten znany był pod nazwą g e o m e trody namiki ${ }^{11}$. W jego

8 Ze względu na równoważność masy i energii wygodniej jest mówić po prostu o energii-masie.

9 Por. np. J. B. Zeldowicz, I. D. Nowikow, Strojenije i ewoljucija wsjeliennoj, Nauka, Moskwa 1975; R. Brout, F. Englert, E. Gunzig; The Causal Universe, General Relativity and Gravitation, 10, 1979, 1-5; Ya. B. Zel'dovich, Cosmology and the Early Universe, w: General Relativity - An Einstein Centenary Survey, ed. by S. W. Hawking and W. Israel, Cambridge University Press, 1979, ss. 518-532.

10 Por. np. F. Wilczek, The Cosmic Assymetry between Matter and Antimatter, Scientific American, 243, 1980 (nr 6), 60-68.

11 J. A. Wheeler, Geometrodynamics, Academic Press, New York 1962; por. także: Ch. W. Misner, K. S. Thorne, J. A. Wheeler, Gravitation, Freeman and Comp., San Francisco, 1973. 
realizacji osiągnięto niezaprzeczalne sukcesy, ale pozostało wiele nieprzezwyciężonych dotychczas trudności. Obecnie uwaga teoretyków kieruje się raczej ku programom związanym z tẹoriami unifikującymi grawitację $z$ innymi polami fizycznymi.

Wspomnieć. wreszcie wypada, że dzieje teorii względności od samego początku były związane $\mathrm{z}$ zagadnieniem masy. Jednym $\mathrm{z}$ głównych motywów stworzenia nowej teorii grawitacji - obok postulatu równoważności masy bezwładnej i masy grawitacyjnej - była dla Einsteina chęć wcielenia do fizyki tzw. z as a dy M a cha. Nazwą tą Einstein określał doktrynę głoszonną, że masa nie jest własnością „,wsobną" danego ciała, lecz że jest indukowana danemu ciału przez inne masy obecne we Wszechświecie. Dziś wiemy, że Einsteinowska teoria grawitacji (ogólna teoria względności) nie urzeczywistnia zasady Macha w całej pełni: w ogólnym przypadku obecność mas indukuje tylko „niewielką część" masy danemu ciału, pozostała część jest „indywidualną własnością" (własnością absolutną) danego ciała ${ }^{12}$.

\section{CZY FIZYKA JEST NAUKA O MATERII?}

W Science and the Modern World (1925) Whitehead ${ }^{13}$ utrzymywał, że klasyczna fizyka sprzyjała materializmowi, ponlieważ z jej formalizmem zgodne było pojęcie ,prostego umiejscowienia”. Znaczy to, iż wyobrażanie sobie, że ,kawałek materii istnieje w kawałku przestrzeni i w kawałku czasu" było niesprzeczne z teoriami fizyki z jej klasycznego okresu. Ale fizyka wspólczesna odrzuciła koncepcję prostego umiejscowienia na rzecz idei pola sięgającego w nieskończoność; znikła możliwość mówienia o „kawałkach materii”, cząstki rozmywają się do nieskończoności, istnieją wibracyjnie, jak fala. Whitehead uważał, że odbiera to podstawę materialistycznym interpretacjom nauki ${ }^{14}$.

Jak starałem się wykazać, pojęcie materii było już obce fizyce klasycznej, a odejście od ,materialistycznych wyobrażeń fizyki-współczesnej upatruję nie tyle $\mathrm{w}$ zarzuceniu idei prostego umiejscowienia (można by przecież skonstruować pojęcie materii nie umiejscowionej w sposób prosty), lecz w coraz bardziej widocznym usuwaniu pojęcia materii poza obszar fizyki. Jeżeli bowiem w zredukowaniu masy do parametru charakteryzującego punkt (tzw. ,punkt materialny”) można by się jeszcze dopatrywać skrajnej idealizacji dawniej intuicyjnego pojęcia materii, to jest to już całkiem niemożliwe, gdy mamy do czynienia z generowa-

12 Por. D. J. Raine, M. Heller, The Science of Space-Time, Pachart Publishing House, Tucson 1981.

13 Collins, Fontana Books, 1975.

14 Por. np. mój artykuł o Whiteheadzie w: M. Heller, J. Życiński, Wszechświat. i filozofia, PWT, Kraków 1980, ss. 101-110. 
niem masy przy pomocy mechanizmu Higgsa, zgodnie z którym masa wywodzi się z czysto formalnie rozumianego łamania symetrii, czy w przypadku różnych koncepcji tworzenia masywnych cząstek z fluktuacji próżni. Pojęcie masy we współczesnej fizyce zdecydowanie przestało odpowiadać filozoficznemu lub potocznemu pojęciu materii.

Nic więc dziwnego, że materialność zaczęto z czasem wiązać z fizycznym pojęciem energii. Już w XIX wieku znany był system filozoficzno-przyrodniczy, zwany energetyzmem, propagowany przez W. Ostwalda, dopatrujący się $w$ energii elementarnego tworzywa materialnego świata, a z zasady zachowania energii niejednokrotnie wyciągano bardzo daleko idące wnioski światopoglądowe ${ }^{15}$. Jak ta sprawa wygląda w świetle współczesnej fizyki? Teoria względności postawiła znak równości pomiędzy energią i masą pomnożoną przez prędkość światła do kwadratu. Energia w fizyce jest zawsze definiowana $z$ dokładnością do addytywnej stałej; innymi słowy - na skali jednostek, w jakich mierzy się energię, nie ma naturalnego zera. Tego rodzaju zera dostarczyło dopiero odkrycie równości energii i masy: za naturalny, ,zerowy” poziom energetyczny można uznać masę spoczynkową rozważanej cząstki. W ten sposób problem energii całkowicie redukuje się do problemu masy. Można by napisać obszerne studium o ewolucji pojęcia energii w nauce, ale ostatnie rozdziały tego studium musiałyby się pokryć z końcowymi partiami studium o rozwoju pojęcia masy.

Okazuje się więc, że określanie fizyki jako ,nauki o materialnym świecie”, lub krócej jako „nauki o materii”, jest niczym innym, jak tylko nawykiem myślowym, który utracił obecnie jakiekolwiek uzasadnienie. Termin „materia” nie występuje w słowniku fizyki. Nie jest to ani termin tecretyczny, ani obserwacyjny; nie posiada on również definicji operacyjnej. Jeżeli pojawia się jeszcze tu i ówdzie w podręcznikach fizyki, to można się na to zgodzić jedynie jako na skrót myślowy zaczerpnięty $\mathrm{z}$ języka potocznego, umieszczony nie $\mathrm{w}$ warstwie tekstu fizycznego lecz w warstwie komentarza do niego.

\section{FIZYKA I OBRAZ SWIATA}

Jedną z głównych kulturowych funkcji nauki jest dostarczanie elementów, z których mniej lub bardziej wykształceni ludzie danej epoki budują sobie „obraz świata". Na obraz taki, oprócz treści pochodzących z nauki (często zresztą mocno stylizowanych lub wręcz zniekształconych), składają się treści pochodzące $z$ filozofii, tradycji, religii i innych, niekiedy trudnych do zidentyfikowania, źródeł. W czasach nowo-

15 Por. np. rozdział pit. „Zasady zachowania i wieczności materii” w mojej książce: Wobec Wszechświata, Wyd. Znak, Kraków 1970 ss. 187-193. 
żytnych tego rodzaju „obraz świata" bywa coraz bardziej impregnowany elementami, o których się sądzi, iż są danymi naukowymi. Za taką „daną nauki" powszechnie się dziś uważa przekonanie, że tworzywem, czy wręcz budulcem świata jest materia. Niniejsze studium wykazało, że przekonanie to $\mathrm{w}$ chwili obecnej nie ma żadnych podstaw.

Ponieważ posiadanie jakiegoś obrazu świata jest nieuniknione, obraz materii-budulca należy zastąpić innym obrazem. Znacznie bardziej zgodnym z „danymi” współczesnej fizyki byłoby wyobrażenie sobie nie materii lecz czystej formy jako tworzywa świata. Wszystkie modele rzeczywistości konstruowane przez nowoczesną fizykę są modelami matematycznymi; nie ma w nich nic poza kształtem, strukturą, czysto formalnym schematem. Funkcja eksperymentu, w istocie rzeczy, polega tylko na identyfikowaniu tych struktur formalnych, które nie mogą być modelami świata (falsyfikacja modeli). Jeśli nawet rzeczywisty świat zawiera coś oprócz formy, to metoda dzisiejszej fizyki nie jest w stanie sięgnąć do tego czegoś; to coś niezauważalnie przepływa przez oka sieci matematyczno-empirycznej metody. W tym sensie świat fizyki jest czystą formą.

Tę samą myśl można wyrazić przy pomocy innego obrazu. Jeżeli informację określić (za współczesną teorią informacji) jako zacieśnianie możliwości ${ }^{16}$, to każde prawo fizyki jest informacją, gdyż ogranicza ono możliwości przyrody ${ }^{17}$. Nasuwa się myśl, że tworzywem świata jest nie co innego jak tylko informacja ${ }^{18}$. Ale znowu - współczesne rozumienie informacji (Shannona teoria informacji) jest czysto formalne. Informacja sprowadza się do struktury, a nie do tego, co tę strukturę może ewentualnie wypełniać. W tym ujęciu struktura świata jest kodem informacyjnym. Zadaniem nauki jest ten kod złamać, odczytać informację, którą jes t struktura świata.

\section{EVOLUTION OF THE MASS CONCEPT}

S u m mary

The term "mass", as being non-operational, does not belong to the vocabulary of physics. Nevertheless it is often believed that physics is a ,science about. matter" and that the concept of mass is an operationistic counterpart of the concept of matter. The evolution of the mass concept is studied. It is shown that the concept of mass in contemporary physics has nothing in common with that of matter. Some remarks concerning the notion of energy are made.

${ }^{16}$ Por. np. M. Heller, M. Lubański, Sz. Slaga, Zagadnienia filozoficzne wspótczesnej nauki, ATK, Warszawa 1980, s. 75. 189.

17 Por. W. Ross Ashby, Wstęp do cybernetyki, PWN, Warszawa 1963, ss. 186-

18 Obszerniej por. np.: M. Lubański, Wprowadzenie do informatyki, ATK, Warszawa 1979, s. 204; M. Heller, Questions to the Universe, Pachart Publishing House, zwłaszcza „Lecture 1”, w druku. 